\title{
INSTITUTIONAL SHAREHOLDERS AND CORPORATE GOVERNANCE: DO INSTITUTIONAL SHAREHOLDERS HAVE AN ACTIVE PARTICIPATION IN PREVENTIVE GOVERNANCE IN THE UNITED KINGDOM? AND IF SO, HOW?*
}

\author{
GOBIERNOS CORPORATIVOS E INVERSIONISTAS \\ INSTITUCIONALES: ¿TIENEN LOS INVERSIONISTAS \\ INSTITUCIONALES UNA ACTIVA PARTICIPACIÓN EN \\ PREVENTIVE GOVERNANCE EN EL REINO UNIDO? ¿CÓMO?
}

\section{Christian ANGUITA OYARZÚN**}

\begin{abstract}
In this paper the author examines the approach of institutional shareholders to Corporate Governance in the United Kingdom, in particular the issue of preventive governance according to the Combined Code of United Kingdom. Corporate Governance has been developed to solve the agency dilemma that exists in modern corporations. Plenty of legislation has been issued around the world to prevent the scandals of the past; however business needs flexible principles for reasons of efficiency. An important role is played by institutional shareholders. The main thesis of this paper is that preventive governance is the best way to solve the agency dilemma and institutional shareholders have learned the importance of it.
\end{abstract}

Key words: corporate governance, institutional investors, preventive governance, agency dilemma, codes of best practices.

RESUMEN: En este trabajo el autor examina la posición adoptada por los inversionistas institucionales en relación con los gobiernos corporativos en el Reino Unido, particularmente en lo referente al tema de preventive governance en el marco del Código Británico de Buen Gobierno Corporativo. El estudio de los gobiernos corporativos ha sido desarrollado para resolver el denominado agency dilemma existente en las corporaciones modernas. Una gran cantidad de leyes se han desarrollado para prevenir los escándalos corporativos del pasado, sin embargo el comercio necesita principios flexiles por razones de eficiencia. Este trabajo pretende demostrar que preventive governance es el mejor camino para resolver el dilema de agencia y que los inversionistas institucionales han aprendido la importancia de esto.

Palabras clave: Gobiernos Corporativos, inversionistas institucionales, preventive governance, agency dilemma, códigos de buen gobierno.

\footnotetext{
* Extracto de la tesis elaborada por el autor para obtener el grado de Master of Laws (LL.M International Commercial Law) en la Universidad de Dundee (Reino Unido).

** Licenciado en Ciencias Jurídicas Pontificia Universidad Católica de Chile. LL.M Internacional Comercial Law, Dundee University (Reino Unido). LL.M French \& European Law, Université de Cergy-Pontoise (Francia). Correo electrónico: cfanguita@gmail.com
} 


\section{THE AGENCY DILEMMA}

\section{A) AGENCY THEORY AND TRANSACTION COSTS IN LISTED COMPANIES}

Historically the pattern of ownership in British companies has been dispersed and the business control been in the hands of the board, this separation of ownership and control leads to the problem that economist had called the agency dilemma. In essence, the theory perceives the governance relationship as a contract between shareholders (the principal) and directors (the agent $)^{1}$, and then agency theory utters a fundamental problem in organizations-self-interested behaviour. A corporation's manager could have personal goals that compete with the owner's goal of maximization of shareholder wealth. When shareholders authorize managers to administer the firm's assets, a potential conflict of interest exists between the two groups and as Adam Smith stated more than two hundred years ago: "the directors of companies being managers of other people's money cannot be expected to watch over it with the same vigilance which they watch over their own" (Adam Smith 1776).

The challenge in the Agency Dilemma is to try to ensure that the agent acts solely in the interest of the principal. The power of the agent has increased steadily during the last decades in listed companies, hence the importance on the ability of the shareholders effectively to monitor and respond to the directors' oversight of the corporation ${ }^{2}$.

The problem of the separation of ownership and control was first developed by Berle and Means who showed that no longer big corporations were controlled by the owners due to the changing nature of ownership in large companies ${ }^{3}$. They saw that this combination of capitalization through liquid securities markets and management by salaried professionals presented problems of responsibility ${ }^{4}$. In the same line, Jensen and Meckling (1976), argued that agency costs are an inevitable part of the management/ ownership, formalised this hypothesis into a mathematical model, and they defined an agency relationship as:

“(...) A contract relationship which one or more persons (the principal) engage another person (the agent) to perform some service on their behalf which involves delegating some decision making authority to the agent. If both parties to the relationship are utility maximizers, there is good reason to believe that the agent will not always act in the best interests of the principal".

The definition above reflects clearly the agency dilemma in modern large corporations, and the main objective for Corporate Governance will consist in developing the best ways to reduces these agency costs in the relationship between the shareholders (principal) and directors (the agents). As Professor Tricker pointed out, the

\footnotetext{
${ }^{1}$ FAMA and JENSEN (1983) p. 327.

${ }^{2}$ Shu-Acquaye (2006-2007) p. 583.

3 Berle y Means (1932) p. 130.

${ }^{4}$ Idem at 131.

5 JeNSEN and MecKLING (1976) p. 309.
} 
conceptual underpinning of Corporate Governance codes around the world and the demands of company law for checks and balances is the need to respond to the agency dilemma ${ }^{6}$.

Furthermore, in today's listed companies agency relationships are complex and the principal cannot be determinated easily, for example, and individual owner might invest funds trough a financial adviser, who invests the funds in a mutual fund or investment trust, which in turn seeks to gear its portfolio by investing in a hedge fund, which invests its resources in a range of equities, property, commodities, and other hedge funds. Tracing the chain of Agencies in such cases can be difficult; however the agency dilemma potential exists throughout the chain.

In the same line, one of the most important objectives of Corporate Governance is to establish the guidelines of the information that must be provided by the company to their owners, information that must be clear, transparent and actualized which must motivate potential investors to invest in the company and give to the actual owners a real state of their business.

One fact is clear: directors know more about the corporate situation than the shareholders whose must demand access to information over and above the minimum required by regulation and company law. What is important is to make sure that the right questions get asked and that checks and balances are in place to make sure that the information provided reflect the real situation of the company and then avoid the meltdowns, frauds and other catastrophes of the past.

One of the most important issues in corporate law and Corporate Governance in particular, is directly linked with the objective of the corporation as a whole and what are the legal rules that directors must follow in the management of the company, specifically if the directors in reaching their decisions must regard only the interest of the principal or also the interest of other constituencies.

\section{B) SHAREHOLDERS PRIMACY}

The debate on whether management should run the corporation solely in the interests of shareholders or whether it should take account of other constituencies is almost as old as the first writings on corporate governance. Professor Berle held the view that corporate powers are capacities in trust for shareholders and nobody else. But, Professor Dodd argued that: "[business] is private property only in the qualified sense, and society may properly demand that it be carried on in such a way as to safeguard the interests of those who deal with it either as employees or consumers even if the proprietary rights of its owners are thereby curtailed". Berle disagreed on the grounds that responsibility to multiple parties would exacerbate the separation of ownership and control and make management even less accountable to shareholders.

According to the shareholder theory, the general aim of Corporate Governance is to improve how the company is run and managed so as to achieve the desired returns for

6 TRICKER (2008) p. 218. 
its investors?. According to Berle, "all powers granted to a corporation or to the management of a corporation, or to any group within the corporation . . . [are] at all times exercisable only for the rateable benefit of all the shareholders as their interest appears" 8 .

One of the main arguments in favour of the shareholder supremacy is provided by the the scholars of the Contractarian Theory, whose regards the company as a sum of complex, private, consensual contract-based relations ${ }^{9}$, where the main contract is the one between the members of the board and the shareholders and under this premise directors have the main duty to enhance shareholders value, who at the end of the day are the owners of the company ${ }^{10}$, and the ones who take the risk through the investment of their own money.

They add that in a world of incomplete contracts, shareholders are relatively less well protected than other constituencies, and that most workers are not locked into a firm specific relation and can quit at reasonably low cost. Similarly, creditors can get better protection by taking collateral or by shortening the maturity of the debt. Shareholders, on the other hand, have an open-ended contract without specific protection. They need protection the most. Therefore, Corporate Governance rules should primarily be designed to protect shareholders' interests as shareholder value reflects the view that shareholders are the owners of the company and bear the residual risk.

\section{C) STAKEHOLDER THEORY}

In the other side we found the Stakeholder Theory which says that directors must take account also the interests of other constituencies in taking the best decisions for the company, then directors are not only to manage the company for the betterment of shareholders, but also in the interests of a multitude of stakeholders (including the shareholders) whose can affect or be affected by the actions of the company ${ }^{11}$.

The stakeholder theory has its maximum exponent in Professor Dodd, who held that the public saw companies as economic institutions that have a social service role to play as well as making profits for shareholders, and that companies had responsibilities to the company's shareholders, employees, customers, and to the general public ${ }^{12}$, it also include more secure jobs for employees, better quality products for consumers, and greater contributions to the welfare of the community as a whole, in the same line we could add environmental and ethical issues in the modern company.

A good example of stakeholder voice in action is the Rover case bring out by Professor Armour and others ${ }^{13}$ on his article "Shareholder Primacy and the Trajectory of UK Corporate Governance", where the activism of non-shareholder constituencies

\footnotetext{
7 BERLE and MEANS (1932) p. 132.

${ }^{8}$ BERLE (1931) p. 1049.

${ }^{9}$ See for example, FAma (1980) p. 290.

${ }^{10} \mathrm{~A}$ kind of property represented by the possession of stock which are freely transferibly.

${ }^{11}$ FreEMAn (1997) p. 69.

12 DODD (1932) p. 1148.

13 ARMour and Others (2003) p. 14.
} 
avoided the plans of BMW to liquidate Rover's business which would have meant the loss of an estimated 24,000 jobs in the Midlands. According to Professor Armour, the Rover case is a reminder that mechanisms exist within UK corporate governance for the representation and articulation of the interests of non-shareholders constituencies and that there are signs that this view is increasingly influencing the attitudes of institutional shareholders in order to engage voluntary cooperation with non-shareholder constituencies in the companies in which they invest.

Unions have an important role in the relationship between the company and other constituencies and they must create a strong linkage with management designed to enhance and sustain corporate performance. The Stakeholder attitude is one of the main characteristic of the German system of Corporate Governance which provides for employee representation on the firm's board of directors. Although Professor Armour is right about the importance of Unions in the company, the system in the United Kingdom of corporate governance does not go as far as the German one.

Case law have also been present in the debate of shareholder and stakeholder primacy, for example in cases like Hutton $v$ West Cork Rly Co and Parke $v$ Daily News $L t d$, generosity to employees was held to be lawful only if it could be justified by reference to the long-term interest of the shareholders.

\section{D) HANSMANN AND KRAAKMAN POSITION}

A clear explanation to conciliate both theories has been given by Professors Hansmann and Krakman in his famous article "The end of history for corporate law", they argue that there is no doubt that companies must be organized and operated to serve the interests of the society as a whole, and that the interests of shareholders do not deserve greater weight than do the interests of any other members of the society, as a consequence of both logic and experience, there is convergence on a consensus that the best means to this end -the pursuit of aggregate social welfare- is to make corporate managers strongly accountable to shareholder interests, and (at least in direct terms) only to those interests ${ }^{14}$.

They argue that the primacy of shareholder interests in corporate law does not imply that the interests of corporate stakeholders must go unprotected. Moreover, other constituencies are protected by other mechanisms than corporate law. Employees mainly through labor law, consumers have antitrust law, safety regulation and tort law, also for the public at large there are environmental law and mass torts ${ }^{15}$.

\section{E) ECONOMICS REASONS TO JUSTIFY SHAREHOLDER PRIMACY}

An important source of the success of the shareholder primacy model is that, in recent years, scholars and other commentators in law, economics, and business have developed persuasive reasons to believe that this model offers greater efficiencies than the principal alternatives. A second reason is that if the control rights granted to the

\footnotetext{
${ }^{14}$ HANSMANN and KRAAKMAN (2000) p. 9.

${ }^{15}$ Idem at pp. 10.
} 
firm's equity holders are exclusive and strong, they will have powerful incentives to maximize the value of the firm. And a third reason is that the interests of participants in the firm other than shareholders can generally be adequately protected by contract and regulation, so that maximization of the firm's value by its shareholders complements the interests of those other participants rather than competing with them ${ }^{16}$.

Firms organized and operated according to the shareholder model can be expected to have important competitive advantages over firms adhering more closely to other models. These advantages include access to equity capital at lower cost (including, conspicuously, start-up capital), more aggressive development of new product markets, stronger incentives to reorganize along lines that are managerially coherent and more rapid abandonment of inefficient investments.

\section{F) LEGAL REASONS TO JUSTIFY SHAREHOLDER PRIMACY IN THE UK}

Among us, the core institutions of UK financial markets (takeover regulations, corporate governance codes and the law relating to directors' duties) are highly orientated to the shareholder primacy model.

For instance, the City Code proscribed that General Principle 7 and Rule 21 of the City Code proscribe managerial actions which might frustrate a bid. General Principle 7 states:

"At no time after a bona fide offer has been communicated to the board of the offeree company, or after the board of the offeree company has reason to believe that a bona fide offer might be imminent, may any action be taken by the board of the offeree company in relation to the affairs of the company, without the approval of the shareholders in general meeting, which could effectively result in any bona fide offer being frustrated or in the shareholders being denied an opportunity to decide on its merits". Together these rule out defensive tactics by the incumbents once a bid is on the horizon, only in accordance with the wishes of shareholders.

The situation of the UK Combined Code and directors' duties of the Companies Act 2006 will be reviewed in different chapters due to the importance for corporate governance of both instruments.

\section{G) The Enlightened Shareholder Value Approach (ESV)}

After the publication of the Companies Act 2006, a new approach to corporate governance arose in the UK. According to section 172 (1) of the new companies act, directors must promote the success of the company, whose in doing so, must have regard a series of constituencies like the interests of the company's employees, the need to foster the company's business relationships with suppliers and customers and the impact of the company's operations on the community and the environment among other matters.

16 Idem at pp. 12. 
Precisely the Companies Act 2006 has implemented a new principle called enlightened shareholder value which is seen as a radical reform in UK law, although this approach is just a little different from the shareholder value approach.

The concept of ESV appears to be similar to the enlightened value maximization that has been advocated in recent years by Professor Michael Jensen, who states that:

"It is obvious that we cannot maximize the long-term market value of an organization if we ignore or mistreat any important constituency. We cannot create value without good relations with customers, employees, financial backers, suppliers, regulators, communities, and so on ${ }^{17}$.

In considering the objective of the company, the Companies Act 2006, seemed to wish to retain the idea of the shareholders being the ultimate focus of directors, but wanted to have a greater emphasis placed on the company's long term future. Certainly the new approach is more enlightened as directors are required to take into account interests other than those of the shareholder.

The current approach of British law is still shareholder supremacy theory, but now directors must take account the interests of other constituencies in the management of the company, regarding mainly long-term value and new concepts of value in the modern economy such as environmental issues. In doing so, directors do not have to forget that they are agents of the shareholders and through the disclosure of information in the annual account show to them the real state of the company. In the next chapters we will review what are the tools that corporate governance has developed to deal with the agency dilemma and make directors more responsible to their principals, stressing the importance in mechanisms of preventive governance.

\section{CODES OF BEST PRACTICE}

\section{A) IMPORTANCE OF CORPORATE GOVERNANCE}

According to the OECD "Corporate Governance involves a set of relationships between a company's management, its board, its shareholders and other stakeholders... [it] also provides the structure through which the objectives of the company are set, and the means of attaining those objectives and monitoring performance are determined"18.

The first thing to be said is the international dimension of Corporate Governance due to the free movement of equity around the world which allows to bring foreign investment into national companies, hence the development of new policies surrounding Corporate Governance among international and national bodies.

Among these relationships, two of them are particularly important for Corporate Governance, the one between the $\mathrm{CEO}$ as a key actor within the top management team and the board of directors, as an indicator of internal governance relationship, the second

17 JENSEN (2001) p. 309.

18 OECD Principles of Corporate Governance (2004) p. 11. 
one refers to the relationship between the firm and its equity investors as an indicator of external governance relationship ${ }^{19}$, for instance between the board or the CEO and institutional investors, which has acquired enormous importance during the last decades.

In this chapter we will analyse some of the efforts made by the national authorities and the international community in order to develop principles of good practice in Corporate Governance, especially the ones which pointed out the importance and participation of institutional investors inside the company.

\section{B) THE CADBURY RePORT}

In 1992, the Cadbury Report was produced by a Committee chaired by Sir Adrian Cadbury in response to a series of corporate failures in the United Kingdom that occurred in the late 1980 s and early $1990 \mathrm{~s}^{20}$, and one of the most important reasons to chair this Committee was to help restore investor confidence, likewise preventing future corporate debacles.

The proposals of the Cadbury Report mainly seek to contribute positively to the promotion of good corporate governance as a whole ${ }^{21}$, and to achieve this objective recommended the creation of a Code of Best Practice to reach high standards of corporate behaviour ${ }^{22}$. This requirement will enable shareholders to know where the companies in which they have invested stand in relation to the Code ${ }^{23}$, mainly through the disclosure of information made by the company.

The Cadbury Committee viewed the importance of institutional shareholders and identified how now the majority of shares of quoted companies are own by pension funds, insurance companies, unit trusts, investment trust among others. In doing so, the Committee pointed out three key points which are basic in the development of a constructive relationship between companies and institutional investors:

i) Dialogue between institutional investors and the board.

ii) Positive use of voting rights by institutional investors.

iii) Institutional shareholders should take a positive interest in the composition of the board, especially in the appointment of non-executives directors ${ }^{24}$.

Another important issue pointed out by the Cadbury Report is the split of the roles of the CEO and the Chairman of the Board, especially having regards the Maxwell affair, where Robert Maxwell held the positions of CEO and Chairman in his publicly traded companies ${ }^{25}$ which ended with the greatest fraud of the $20^{\text {th }}$ century. Such

\footnotetext{
${ }^{19}$ Aguilera and Others (2006) p. 148.

${ }^{20}$ Among others, the collapse of the BCCI bank, Guinness, Polly Peck and the Robert Maxwell affaire.

${ }^{21}$ CAdbury Report (1992) para. 1.2.

22 Idem, para 1.3.

23 Idem.

${ }^{24}$ Idem para. 6.11.

25 Maxwell Communication Corporation from 1981 to 1991 and Macmillan Publishers from 1988 to 1991.
} 
undivided control is now considered to represent corporate governance weakness ${ }^{26}$. In the same line, Principle A.2 of the United Kingdom Combined Code of 2008 states that "there should be a clear division of responsibilities at the head of the company between the running of the board and the executive responsibility for the running of the company's business". No one individual should have unfettered powers of decision'.

\section{C) The Hampel RePORT}

In 1998, the Hampel Report confirmed the role of institutional shareholders developed by the Cadbury Committee and additionally pointed the difference existent among the institutional shareholders which usually have different investment objectives, adding that typically institutions used notto take much interest in corporate governance and to intervene directly with company managements only in circumstances of crisis ${ }^{27}$. It is important to notice that the observation made by the Hampel Report was before the Asian crisis, and that since then, the interest of corporate governance has been a key issue for institutional investors. Again, Hampel stated the importance of institutional shareholders in the promotion of best practices voting on resolutions in General Meetings, and informally through contact with the company ${ }^{28}$.

The Hampel Report specifically examined the way in which institutional investors could contribute to the realization of the existing code. In this context, section 5, "The Role of Shareholders" of the Hampel Report noted that:

"60 per cent of shares in listed UK companies are held by UK institutions - pension funds, insurance companies and investment trust. Of the remaining 40 per cent about half are owned by individuals and half by overseas owners, mainly institutions. It is clear from this that a discussion of the role of shareholders in corporate governance will mainly concern the institutions, particularly UK institutions". (sub-section 5.1)

\section{D) The Higgs RePOrT}

In the Higgs Report (2003) the importance of overseas investors is recognized within the UK equity market and the "institutionalization" of the market has been pointed as the most important change during the last decades which more than half of the equity capital of UK listed companies hold by pension funds, insurance companies, pooled investment vehicles (for example unit and investment trusts) and other financial institutions such as charities, endowments and educational institutions ${ }^{29}$. Enhancing the importance for regular meetings between the company's major shareholders and the chief executive, the Chairmen often also participate ${ }^{30}$, but Higgs suggest that

\footnotetext{
${ }^{26}$ Emblematic is the case of Sir Stuart Rose who is the CEO and Chairman of Marks \& Spencer.

27 HAMPEL REPORT (1998), para. 5.3.

28 Idem.

${ }^{29}$ Higgs (2003) para. 15.2.

${ }^{30}$ Idem para. 15.4
} 
relationships between non-executive directors and shareholders could and should be closer $^{31}$, without executive management present ${ }^{32}$.

Moreover, Higgs Report suggests that firms should appoint a "senior independent director" which may constraint even more the power of the CEO. This change seems likely to spread the power at the top of the firm by enhancing the power of the board of directors to operate independent of management and effectively monitor executive action.

As seen above, following the advice provided by Sir Adrian Cadbury, the United Kingdom has developed a periodical revision of principles of corporate governance and issued different version of its Combined Code, the latest version was issued in 2008 by the Financial Reporting Council ${ }^{33}$, which contains a section only dedicated to institutional shareholders ${ }^{34}$.

E) The UK COMBIned COde (2008)

According to the UK Combined Code (2008) the key points, as stated for the Cadbury Report in 1992, in the participation of institutional shareholders in the corporate governance of companies are the follows:

i) Dialogue with companies: mainly based on the mutual understanding of objectives.

ii) Evaluation of governance disclosures: when evaluating companies' governance arrangements, particularly those relating to board structure and composition, institutional investors should give due weight to all relevant factors drawn to their attention.

iii) Shareholder voting: they have a responsibility to make considered use of their votes.

\section{F) COMPLY OR EXPLAIN}

According to the Listing rules, all companies incorporated in the UK and listed on the Main Market of the London Stock Exchange are required to report on how they have applied the Combined Code in their annual report and accounts.

Listed companies are required to report on how they have applied the main principles of the Code, and either to confirm that they have complied with the Code's provisions or -where they have not- to provide an explanation, hence the "comply or explain" principle.

Although the Code had no legislative basis and enforcement, failure to meet its requirements could lead to de-listing from the Exchange. De-listing, however, would

\footnotetext{
${ }^{31}$ Idem para. 15.9

32 Idem para. 15.12.

${ }^{33}$ The Financial Reporting Council is the UK's independent regulator responsible for promoting confidence in corporate governance and reporting.

34 UK COMBINED CODE (2008) section 2.
} 
tend to disadvantage the very shareholders whom the corporate governance codes were designed to protect, so de-listing was a last resort (and in fact never used) ${ }^{35}$. More than a mandatory enforcement, the Code through its "apply the code or explain why not" philosophy has become a reputation indices which investors watch every day more if they are thinking whether or not to invest in a listed company and is precisely the market which monitor compliance with a code or will either penalise non-compliance through lowering share prices ${ }^{36}$.

The Combined Code on Corporate Governance ('the Code') is published by the Financial Report Council to support efficient, effective and entrepreneurial management that can deliver shareholder value over the longer term and to promote confidence in corporate reporting and governance. The Code is not a rigid set of rules, but is an effective alternative to a rules based system ${ }^{37}$ and a condition sine qua non of non-compliance is that the reasons for it should be explained to the shareholders, who may wish to discuss the position with the company and whose voting intentions may be influenced as a result ${ }^{38}$.

The "comply or explain" principle is based on the assumption that the market will monitor compliance with a code and will either (a) penalise non-compliance through lowering shares prices or (b) accept that non-compliance is justified in the circumstances, for instance, good performance of the company. According to this view, companies have an incentive to comply because the Code represents the view of institutional investors as to best practice and therefore the onus is on a non-compliant company to justify its position, hence a decision to comply is likely to carry benefits for a company's share price ${ }^{39}$.

In contrast to the fiduciary duties, the "comply or explain" approach can be considered to be an example of ex ante rules by creating board structures and procedures that will minimise the likelihood of any question of breach of fiduciary duty arising ${ }^{40}$. Another consideration to adopt the "comply or explain" principle is flexibility, where companies may adjust the principles issues by corporate governance codes depending of its size, structure and organization.

\section{G) THE IMPORTANCE OF THE BRITISH EXPERIENCE IN THE WORLD}

The Cadbury Report is seen as the benchmark for corporate governance codes, which provides an example of "soft-regulation" 41 and enhance the "comply or explain" principle that has been emulated in many countries ${ }^{42}$. But only in Hong Kong, Australia, Canada, India, Singapore, South Africa (mainly Commonwealth countries)

\footnotetext{
35 TRICKER (2008) p. 148.

36 MACNEIL and Li (2006) p. 487.

37 Directors' fiduciary duties in the Companies Act 2006.

38 UK COMBINED CODE (2008) preamble.

${ }^{39}$ MALLin (2001) p. 77-78.

40 See footnote 37 at 487 .

${ }^{41}$ Instead of hard laws, such as the United States with the Sarbanes-Oxley Act 2002.

42 By mid 2008, 64 countries had issued 196 distinct codes of governance.
} 
corporate governance regulation is based on compliance with codes of principles and good practices ${ }^{43}$.

The spread of codes of Corporate Governance has also been promoted by international entities, such as the World Bank, the International Corporate Governance Network (ICGN) and the Organization for Economic Cooperation and Development (OECD) which highlight the need to improve corporate governance to help countries grow and develop ${ }^{44}$. However, the experience has demonstrated that they are more likely to emerge in countries with a common-law legal system. A lack of strong shareholders' protection rights, high government liberalization, and a strong presence of foreign institutional investors have been indicated as the main reasons for the existence of the codes ${ }^{45}$.

An important debate in the international corporate governance context is whether countries should develop hard laws, such as the United States with the Sarbanes-Oxley Act 2002, or whether soft regulation, such as the United Kingdom Combined Code. The Financial crisis has taught us that neither one, nor another is enough to prevent big scandals and avoid lack of business ethics among top management ${ }^{46}$.

Codes of good governance have some key universal principles for effective corporate governance that are common to most countries, most of codes, have some recommendations on the following governances practices, explicitly or implicitly: (1) a balance of executive and non-executives directors, such as independent non-executive directors; (2) a clear division of responsibilities between the chairman and the chief executive officer; (3) the need for timely and quality information provided to the board; (4) formal and transparent procedures for the appointment of new directors; (5) balanced and understandable financial reporting; and (6) maintenance of a sound system of internal control.

These characteristics have been developed by the different committees that have analysed the situation of corporate governance in the United Kingdom and have served as an example followed by other countries. According to Professor Cheffins, The 'comply or explain' approach to corporate governance issues developed by the Cadbury Committee and used subsequently by the Greenbury and Hampel Committees has proved to be highly influential outside the United Kingdom. Additionally, the authors of the Hampel Report said that Cadbury 'struck a chord in many overseas countries; it has provided a yardstick against which standards of corporate governance in other markets are being measured' 47 .

\section{E) INTERNATIONAL BEST PRACTICE}

In the international context there are also institutions which have showed an interest in promoting good corporate governance, especially due to the fact that foreign

\footnotetext{
43 Aguilera and Cuervo-Cazurra (2009) p. 377.

${ }^{44}$ Idem.

${ }^{45}$ Idem, at 381.

46 Among others, Madoff affaire, General Motors, Lemhan Brothers in US and RBS in UK.

${ }^{47}$ HAMPEL (1998) para. 1.5.
} 
investment is a reality in today's economy. Among these institutions, we find the OECD, the World Bank, Internacional Corporate Governance Network and the European Corporate Governance Institute.

The OECD Principles of Corporate Governance were first launched in 1999 and have since become an international benchmark for policy makers, investors, corporations and other stakeholders worldwide. The principles represent guidance for national initiatives in both members and non-members countries of the OECD, the latest version of the OECD Principles was issued in 2004. These principles have been developed attending the importance of corporate governance is one key element in improving economic efficiency and growth as well as enhancing investor confidence. Although these principles does not emphasised the importance of institutional shareholders, aiming the principles for both individual and institutional shareholders, the importance of the use of their voting rights is remarked as an important principle of good corporate governance. These principles are an integral part of the corporate governance policies of the OECD countries and also inspired the non- OECD countries, most of them are represented in the United Kingdom Code of Best Practice or in company law.

In 1995 the International Corporate Governance Network (ICGN) was founded with the mission of developing and encouraging good corporate governance worldwide, ICGN members include institutional investors, business leaders, policy makers and professional advisors. The importance of the ICGN is that has been founded at the instigation of major institutional investors, in doing so, the ICGN represent clearly the thinking of institutional investors worldwide and, among its objective are the development and the promotion of corporate governance standards and guidelines, the promotion of good corporate governance and the exchange of information and education in all matters regarding corporate governance, as stated in its articles of association.

Since 1999 the ICGN has drawn their own Statement on Institutional Shareholder Responsibilities, been the latest version from 2007. Regulars conference are also held by the ICGN around the world which all institutional investors analyse and discuss actual issues in corporate governance and making recommendations to raise standards in corporate governance.

In Europe, the European Corporate Governance Institute (ECGI) is a forum for debate and dialogue between academics, legislators and practitioners, focusing on major corporate governance issues and thereby promoting best practice.

Throughout this chapter have been demonstrated how important corporate governance is for all the participants of the financial markets, not only for the government which make a periodical review since 1992, but also for institutional investors, international organisms and companies with many of them issuing their own code of best practice of corporate governance. We also analysed the importance of corporate governance in today's economy and seen the efforts made by the government and international institutions to create a flexible mechanism that allow companies to control the relationship between shareholders and the board.

In the next chapter we will study the institutional investors and their initiatives in good practice to complement the principles issued by the authority. 


\section{INSTITUTIONAL SHAREHOLDERS}

\section{A) IMPORTANCE OF INSTITUTIONAL SHAREHOLDERS WITHIN THE UK}

In the United Kingdom the level of share ownership by individuals has decreased over the last thirty years, whilst ownership by institutional investors has increased. These institutional investors comprise mainly pension funds and insurance companies. Even the Cadbury Committee viewed institutional investors as having a special responsibility to try to ensure that its recommendations were adopted by companies.

In the traditional United Kingdom listed company, most decisions about the company's business are taken by the board, hence the importance of the ability of the shareholders to review the performance of the board (especially when the annual report and accounts are presented to them) and to take decisions if they think that performance has not been adequate, for example, by removing the existing directors and installing a new board ${ }^{48}$. Considering their importance and responsibility in the economic life, even some reformers have proposed that institutional investors could be obliged to attend shareholder meetings ${ }^{49}$.

United Kingdom institutional investors have been encouraged to play a more active role in the governance of companies since the Cadbury Report, and with more impetus from the Myners' Review in 2001, which stress the importance of institutional investors as a public policy interests which equity represents the savings of millions of people, consequently the ability of institutions to invest these assets effectively has a profound impact on their economic well-being, likewise the decisions of institutions in the United Kingdom play a critical role in productivity and economic growth ${ }^{50}$.

Both the Company Law Review and the Myners' Report, commissioned by the Treasure, concluded that the level of institutional intervention in the affairs of their portfolio companies was less than was optimal in the interests of those on whose behalf the institutions invested.

\section{B) IDENTIFYING INSTITUTIONAL SHAREHOLDERS}

The largest groups of shareholders are individualized as foreign institutions, pension funds, mutual funds, and insurance companies. According to Bob Monks, these institutions have one very significant thing in common. All are subject to the highest standard of care and prudence, the fiduciary standard as all institutional investors are acting on behalf of others. However the groups of institutions have little in common with each other, as we will see below.

\section{C) The Role of Institutional Investors in Corporate Governance}

Bob Monks, one of the most famous and reputed shareholder activist, pointed out that the single major challenge addressed by corporate governance is how to grant

\footnotetext{
48 COMPANIES ACT (2006), section 168.

49 City/Industry Working Group (1995) p. 14.

${ }^{50}$ MYNers (2001) p. 4.
} 
managers enormous discretionary power over the conduct of the business while holding them accountable for that power arguing that managers must be given the power to make decisions quickly and to take reasonable risks. If every managerial decision had to be communicated to the company's owners, much less ratified by them, industrial progress would be paralyzed, and everyone would lose.

As directors are representatives of the owners, the board's primary role is to monitor management on behalf of the shareholders and directors must be accountable to them. Institutional investors are beginning to use their influence to monitor performance by companies across a range of social and environmental issues which impact upon stakeholders. This is being done not solely for ethical motives, but also because ignoring stakeholder issues might put shareholders interests at risk. This influence is exercised by their voting rights, ongoing dialogue and the evaluation of governance disclosure. Additionally, those controlling large block of shares have demanded regular management contact.

Aware of their importance, institutional shareholders have created a new movement called "Institutional shareholders activism" in order to organize themselves to reach the higher standards in corporate governance. Among us, there are two representative bodies which act as a professional group 'voice' for the views of large institutional investors; these are the Association of British Insurers (ABI) and the National Association of Pension Funds (NAPF). Both the ABI and the NAPF have best practice corporate governance guidelines which encompass the recommendations of the Combined Code and also they monitor the corporate governance activities of companies and will provide advice to members.

\section{D) InSTITUTIONAL INVESTORS’ CODES OF BEST PRACTICE \\ - Hermes}

Following the same line of the United Kingdom Combined Code and their periodical reviews, some institutional shareholders have issued their own corporate governance principles. A good example of institutional shareholders' influence in the management of the companies in which they invest is Hermes Investment Management Ltd., Hermes is one of the largest pension funds managers in Britain and is a leader activist in issues of corporate performance and social responsibility. Hermes is the first major investment institution in the world to have established an activist fund which invests in companies that are poorly performing but fundamentally sound, with the aim of improving performance and delivering long-term shareholder value through better management and corporate governance.

\section{- Standard Life}

Another important institutional investor in the United Kingdom is Standard Life $^{51}$ which in 1992 set up a dedicated corporate governance team, to develop and implement a professional approach to corporate governance, which aims mainly to

51 One of the major UK institutional investor. 
contribute to long-term investment performance. Their initiative falls into two streams, preventive governance and reactive governance. Preventive governance involves discussions with companies (company secretary, company chairman) to gain a better understanding about the way in which they discharge their corporate governance responsibilities. Reactive governance, on the other hand, arises when corporate governance breaks down ${ }^{52}$.

The example of Standard Life reflects the majority approach of United Kingdom institutional investors which emphasise the importance of their long-term investments, mainly because the pension funds and insurance companies that dominate the United Kingdom equity market have long-term payout obligations, and so might more readily adopt a long-term perspective on the risks and opportunities presented by portfolio companies ${ }^{53}$. In the same line, it persuades them to take carefully consideration over Preventive governance.

\section{E) INSTITUTIONAL SHAREHOLDERS’ ACTIVISM}

\section{- Association of British Insurers}

We also have into consideration initiatives such as the Association of British Insurers (ABI) which also started to show interest in drafting the responsibilities of institutional shareholders, is for that reason that in 1991 launched a discussion paper called "The Responsibilities of Institutional Shareholders" in its campaign to improve corporate governance in the United Kingdom encouraging institutional investors to have regular contact at senior executive level and also a positive use of voting rights.

\section{- Institutional Shareholders' Committee}

Fundamental importance in the development of good practice for institutional investors have had the Institutional Shareholders' Committee (ISC), the ISC is a forum which allows the institutional shareholding community in the United Kingdom to exchange views and, on occasion, coordinate their activities in support of the interests of UK investors and its constituent members are: The Association of British Insurers (ABI), the Association of Investment Companies (AIC), the Investment Management Association (IMA) and the National Association of Pension Funds (NAPF).

The ISC throughout its continues work in enhancing best practice for institutional shareholders in relation to their responsibilities in respect of investee companies has been drawn an Statement of Principles pointing out the necessity for institutional shareholders in monitoring the performance and establish a regular dialogue with investee companies. In its latest paper, in the context of the United Kingdom banking crisis, one of the main purposes is to enhance the quality of dialogue between institutional investors and all companies to help improve long-term returns and the alignment of interests, reduce the risk of catastrophic outcomes due to bad strategic

\footnotetext{
52 JUbB (2000) p. 81-82.

53 Aguilera and Others (2006) p. 150.
} 
decisions or poor standards of governance, and help with the efficient exercise of governance responsibilities.

\section{CORPORATE GOVERNANCE AND COMPANY LAW}

\section{A) GENERAL ASPECTS}

The importance of understanding the different levels of institutional investor protection and clarify the difference between the protections offered by company law in one side, especially throughout the fiduciary duties established in the Companies Act 2006, the biggest reform of United Kingdom companies law for 150 years, and on the other side the level of protection and participation offered by the United Kingdom Combined Code is a basic premise in corporate governance.

The clear preference in business community in the United Kingdom is still for voluntary compliance and the avoidance of legislation as the Hampel Report had indicated. However, revised company law in the Companies Act 2006 clarifying director's duties has sharpened the legal position.

The Companies Act 2006 clarified directors' duties ${ }^{54}$ for the first time in statute law as historically the responsibilities of directors were determined by case law. It makes clear that directors have to act in the interests of shareholders. However, as seen in chapter I previously, they must pay regard to the longer term of other constituencies such as employees, suppliers, consumers and the environment.

The language previously used (by the courts) to describe the obligations of a director were that the director had to act "bona fide in the best interests of the company". In essence, this obligation is repeated in the Act, the obligation of good faith remains and it is the company's interests, defined as the benefit of its members as a whole that must be advanced. What has changed is that the Act now prescribes not only the basic duty of the director, but how the director must go about discharging that duty. The director must now have regard to the specific matters set out in section 172(1)(a) to (f). While competent directors have previously had regard to these matters, that process is now part of the directors' statutory obligation.

\section{B) DiReCTORS' Duties}

There are seven general duties in the new statutory statement as follows.

- A duty to act in accordance with the company's constitution, and to use powers only for the purposes for which they were conferred. This replaces existing, similar duties.

- A duty to promote the success of the company for the benefit of its members. This replaces the common law duty to act in good faith in the company's interests.

54 They came into force by October 2008. 
- A duty to exercise independent judgment. There is no exactly equivalent duty at common law. However, directors are currently under an obligation not to fetter their discretion to act or to take decisions - this aspect of the general duty replaces this obligation.

- A duty to exercise reasonable care, skill and diligence. This replaces the existing duty of care and skill.

- A duty to avoid conflicts of interest (except where they arise out of a proposed transaction or arrangement with the company - see below). At present, if a director allows his personal interest or his duties to another person, to conflict with his duty to the company then, unless shareholders consent to the conflict: (i) the company can avoid any relevant contract and (ii) he must account to the company for any 'secret profit' he has made out of the arrangement. The new duty replaces this old rule.

- A duty not to accept benefits from third parties. There is no express duty to this effect at common law. It appears to derive from the current duties to act in the company's interests and the rule dealing with conflicts of interest.

- A duty to declare to the company's other directors any interest a director has in a proposed transaction or arrangement with the company. At present, a conflict of interest arising out of a transaction or arrangement with the company is dealt with by the general rule on conflicts of interest, described above.

Analyzing directors' duties we can arise the conclusion that the new Act assists in protecting directors from shareholder pressure to achieve short term gain at the expense of long term progress, likewise ensuring that all directors are provided with adequate information prior to making any decision.

For instance, a large company manufactures goods in the United Kingdom. The finance director and managing director together draw up a plan to move production to a lower wage cost country abroad. This will save the company a substantial sum, even after taking into account redundancy payments to the United Kingdom factory workers. The manufacturing plant is in an area of high unemployment and its closure is likely to have a significant impact upon the local community.

The directors must also have regard to their business relationships with suppliers and customers. What will be the impact upon sales of the company's products if they are no longer "made in the United Kingdom"? What about the company's relations with the community? Will closure and the redundancy programme have an adverse impact upon the company's reputation and ability to do business?

What about the impact upon the environment? This may be two-folded. Will production in the new location have a positive or detrimental effect upon the environment there? What will happen to the United Kingdom plant that has been closed? How will different energy, transport, waste and material consumption issues affect the company in these two options?

Enforcement of both levels of regulation is an important part to compare the strengths and weaknesses of principles of best practice and fiduciary duties. 


\section{C) DERIVATIVE ACTION}

The Act introduces a new dimension concerning shareholders rights to sue directors, in the company's name, to recover on its behalf loss it has suffered as a result of director's negligence. They will also be able to claim against third parties implicated in any breach.

The government has made some effort to respond to these concerns, by introducing a two stage process for derivative claims. First, a disgruntled shareholder will have to apply to the court for permission to make the claim - if the court considers that the evidence filed by the applicant does not make out a prima facie case, it will be required to dismiss the application ex parte at this stage. If an application survives this process, it will enter the second stage, during which the court will decide, based on the evidence of both sides, whether the claim should be allowed to proceed. At this stage a range of factors will be taken into account -including the views of independent shareholders with no personal interest in the matter. Companies may find it helpful to approach institutional shareholders for support. Only if the claimant is successful will the claim progress to the third stage- a full trial of the issues.

There is still a risk that activist shareholders and pressure groups will seek to use the new procedures at least to create publicity and put decisions of public company boards under even greater scrutiny. Directors may want to have in place a response plan if action is threatened.

In the longer term we do not believe that institutional shareholders will use the derivate action granted by the CA 2006 as, at the end of the day, will cause only prejudice to their own investment. In contrast, the derivate action would constitute a dangerous tool for shareholders who hold a small percentage of shares and could be unhappy for the long-term value of their shares.

\section{D) COMPARATIVE ANALYSIS OF THE PROTECTION PROVIDED BY THE UNITED Kingdom Combined Code And THE Companies ACT 2006}

Currently, institutional investors have a double stage protection, in first place, the United Kingdom Combined Code offer an ex ante regulation formed by the principles of best practice which promote preventive governance aimed to obtain long-term value through the continuing cooperation between shareholders and the board.

The Companies Act 2006 clearly stated directors' fiduciary duties and, perhaps, the big advantage is the enforcement of their rules and, in doing so, directors must be aware of managing the company in the terms of the CA 2006, because if they do not comply with the CA, they will be in a serious risk of breaching their fiduciary duties and shareholders could use the derivate action. CA 2006 is a clear example of reactive governance.

\section{INSTITUTIONAL SHAREHOLDER IN ACTION}

The tools of corporate governance for institutional investors are an essential part in the relationship between the board and institutional shareholders where the objective 
is to present a complete account of institutional investors' forces within the board and measure what is the real influence in the board's decisions.

\section{A) Dialogue}

A clear communication and dialogue between the board and institutional shareholders has been remarked as one of the most important tools for good corporate governance by the different corporate governance reviews and codes of best practice, likewise by the international institutions and associations of Institutional Investors.

According to the latest version of the Code, "There should be a dialogue with shareholders based on the mutual understanding of objectives. The board as a whole has responsibility for ensuring that a satisfactory dialogue with shareholders takes place" 55 . This principle recognize that the most contact is with the CEO and other directors, but also the dialogue with the chairman and other directors is appropriate to understand the issues and concerns of major shareholders. In this attempt the chairman should ensure that the views of shareholders are communicated to the board as a whole.

There is a strong focus on how dialogue between shareholders and boards can be facilitated. This will be welcomed by those fund managers that already have a long-term strategy and are prepared to devote the necessary time and resources to see the potential benefits of active engagement.

In the same line, the Walker Review is realistic about the level of engagement that can be expected - an institutional shareholder will not be involved in management. This must remain the role of the executive. Where institutional shareholders can (and often do) usefully engage is by ensuring that the company's leadership is of the right calibre and performing effectively to set the right strategic goals and ensure they are executed engagement as preventative medicine rather than crisis management.

To establish a definitive list of key governance issues for companies and institutional shareholders, so as to provide a basis for initiating engagement, is probably unrealistic in view of the variety of circumstances that apply to such a significantly large number of companies in an investment portfolio. However, generically these issues will usually fall into one or more of the following categories: board composition, effectiveness and succession; strategy; risk management; capital structure; and remuneration versus performance.

In the climate of constitute a useful contribution to the current Walker Review and the Financial Reporting Council's review of the Combined Code, the ISC recently launched a paper aimed to improve institutional investors' role in governance, especially in the wake of the banking crisis, but it could be applied to all companies as the paper addresses... "[the purpose] through this paper is to enhance the quality of dialogue between institutional investors and all companies" 56 . Whilst a collective approach is suggested, is necessary to enhance investor's ability to ensure that the whole board, led by the chairman, responds to concerns ${ }^{57}$.

\footnotetext{
55 UK Combined Code (2008) Section 1 (D1).

56 Institutional Shareholders' Committee (2009), Improving Institutional Investors' Role in Governance.

57 Idem.
} 
Having regards the financial crisis of 2008, and the urgency to reduce the risk of catastrophic outcomes due to bad strategic decisions or poor standards of governance, the ISC encourage more institutions to participate, creating a broader network that might include foreign investors and sovereign wealth funds with an interest in long-term value and make a call to the authorities to make clear that collective dialogue is permitted.

\section{B) VoTING}

The right to vote is an essential characteristic of voting shares and is a fundamental element of control by shareholders. Recent reviews in corporate governance have promoted the vote on all issues which may be raised at their investee company's AGM and the vote may be directly on all resolutions or by the appointment of a proxy.

As "The Code" pointed out: "Institutional shareholders have a responsibility to make considered use of their votes", they should attend AGMs and take steps to ensure their voting intentions are being translated into practice.

\section{C) Evaluation of Governance Disclosure}

"When evaluating companies' governance arrangements, particularly those relating to board structure and composition, institutional shareholders should give due weight to all relevant factors drawn to their attention".

In doing so, institutional shareholders should:

- Consider carefully explanations given for departure from the Code and make reasoned judgements in each case.

- Give an explanation to the company, in writing where appropriate, and be prepared to enter a dialogue if they do not accept the company's position.

- Avoid a box-ticking approach to assessing a company's corporate governance.

- Bear in mind in particular the size and complexity of the company and the nature of the risks and challenges it faces.

Additionally to the principles of the United Kingdom Combined Code, in today's world, institutional investors recognize the importance of environmental and social issues as integral part of its performance and long-term sustainability which can also generate wealth by creating shareholder value through an increase in business opportunities and broader access to international markets.

The importance of best practice in corporate governance has motivated institutional investors to draft their own best practices policy following the principles ruled by the United Kingdom Combined Code and adding higher requirements to the companies in which they invest.

\section{D) EXIT OPTION}

If all the efforts made by institutional shareholders in order to built a strong link with the company does not work, they have two options: 
- Hold their shares and try to use their power through the voting system in the annual general meeting or;

- Sell their shares, also known as the exit option.

The different United Kingdom Committees have made clear that the exit option is not the best solution for best practice; instead they promote long-term investors to be more closely involved with the corporations whose shares they hold.

The experience show us that the exit option is mostly used by shareholders who have short-term expectative, and thus little interest in participate in the control of the company.

To be fair, the reality is that the most important institutional investors in United Kingdom (pension funds and insurance companies) are long term investors who take corporate governance seriously and have an active behavior in the control of the company.

\section{CONCLUSION}

Considering the importance of the agency dilemma, the United Kingdom has developed flexible, but not less efficient, principles in corporate governance in the last two decades, thanks to the joint working among the government, institutional shareholders, academics and international institutions.

Most of the rules studied are inspired in the shareholder primacy with a longterm approach and an important role of other constituencies, especially since the CA 2006 clearly defined directors' duties and incorporate rigid rules into the area of corporate governance.

The participation of institutional shareholders started slowly, but during the last years has incremented steadily mainly because they are aware of the benefits that brings good corporate governance for their profits and for the society as a whole.

Among institutional shareholders and the business community there is a clear preference to preventive governance, the approach that first developed Sir Adrian Cadbury and that is now impress in the United Kingdom Combined Code. This preference is due mainly for reasons of efficiency as in business decisions must be taken quickly and the power of the managers is a fundamental premise in the success of the company. However, to balance this power, institutional shareholders must have an active relationship with the board, firstly trough an active dialogue and then with a responsible voting and evaluation of governance disclosure monitoring the performance of the board as well.

Over the longer term we should not be surprised to see stronger principles that promote preventive governance, but at the same time reactive legislation will issued in a big quantity, due mainly to the last corporate scandals. Then, institutional shareholders will have a double protection stage, firstly the preventive governance trough the Codes of Best Practice and the protection given by company law, which will be used as ultima ratio. 


\section{BIBLIOGRAPHY}

Aguilera, R. and Others (2006): “Corporate Governance and Social Responsibility: a Comparative Analysis of the UK and the US" 14 (3) Corporate Governance: An International Review, pp. 147-158.

ARMOUR and OTHERS (2003): "Shareholder Primacy and the Trayectory of UK Corporate Governance" ERSC Centre for Business Research, University of Cambridge, Working Paper $N^{\circ}$. 266, 31 p.

BECHT and OTHERS (2005): "Corporate Governance and Control" ECGI Working Paper Series in Finance, Woking Paper $N^{o}$. 02/2002, 128 pp.

Berle, A. and Means, G. (1932): The Modern Corporation and Private Property (New York: Harcourt, Brace \& World) 380 pp.

Berle, A. (1931): "Corporate Powers as Powers in Trust" 44 Harvard Law Review, pp.1049-1074.

CADbury, Sir Adrian (1992): Report of the Committee on the Financial Aspects of Corporate Governance (London, Gee and Co. Ltd.) 90 pp.

Cheffins, B. (2000): "Corporate Governance Reform: Britain as an Exporter" 8 (1) David Hume Institute in Corporate Governance and the Reform of Company Law, Hume Papers on Public Policy, 38 pp.

Company LaW Review Steering Group (2000, URN 00/656): Modern Company Law for a Competitive Economy: Developing the Framework (London, The Company Law Review Steering Group).

DodD, E. (1932): "For Whom are Corporate Managers Trustes?" 45 Harvard Law Review 1145-1163.

FAmA, E. (1980): "Agency Problems and the Theory of the Firm" 99 Journal of Political Economy 288.

FAma, E. and Jensen, M. (1983): "Agency Problems and Residual Claims" 26 Journal of Law and Economics 327-349.

HAMPEL RePORT (1998): Committee on Corporate Governance, Final Report (London, Gee \& Co. Ltd.)

Hansmann, H. and KRAaKman, R. (2000): "The End of History for Corporate Law" Yale International Center for Finance, Working Paper No. 00-09. 37pp.

Higgs, D. (2003): Review of the Role and Effectiveness of Non-Executive Directors (London, Department of Trade and Industry).

Institutional Shareholders' CommitTee (2007): Review of the Institutional Shareholders' Committee Statement of Principles on the Responsibilities of Institutional Shareholders and Agents (London, ISC).

Institutional Shareholders' COMmitTeE (2009): Improving Institutional Investors' Role in Governance (London, ISC).

Jensen, M. and Meckling, W. (1976): "Theory of The Firm: Managerial Behaviour, Agency Costs and Ownership Structure" 3 (4) Journal of Financial Economics 305360. 
Anguita Oyarzún, Christian "Institutional shareholders and corporate governance: Do institutional..."

Jensen, M. (2001): "Value Maximization, Stakeholder Theory and the Corporate Objective Function" 7 (3) European Financial Management 297-317.

MACNEIL, I. and LI, X. (2006): "Comply or Explain": Market Discipline and NonCompliance with the Combined Code" 14 (5) Corporate Governance: An International Review 486-496.

Mallin, C. (2001): "Editorial, Corporate Governance and the Bottom Line" 9(2) Corporate Governance 77-78, commenting on the McKinsey \& Company (2000) Investor Survey on Corporate Governance.

Mallin C. (2007): Corporate Governance $2^{\text {nd }}$ ed. (New York, Oxford University Press) $316 \mathrm{pp}$.

MONKS, R. and MinOw, N. (2008): Corporate Governance (London, Wiley) 651 pp.

Myners, R. (2001): Myners Report on Institutional Investment (London HM Treasury)

OECD (2004): Principles of Corporate Governance (Paris, OECD Publications Service).

O’SHEA, N. (2005): “Governance How We've Got Where We Are and What's Next” 37 (6) Accountancy Ireland 33-37.

SHU-ACQUAYE, F (2006-2007): "Corporate Governance Issues: United States and the European Union” 29 Houston Journal of International Law 583-623.

Tricker, B. (2008): Corporate Governance: Principles, Policies and Practices (New York, Oxford University Press) 431 pp.

UK Combined Code (2008): The Combined Code on Corporate Governance (London, The Financial Reporting Council). 